\title{
Preparation of Subcritical Water-Treated Okara and Its Effect on Blood Pressure in Spontaneously Hypertensive Rats
}

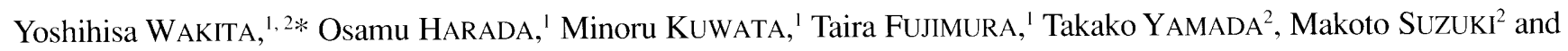 \\ Keisuke TSUJI ${ }^{2}$ \\ 'Department of Product Innovation, Hyogo Prefectural Institute of Technology, Yukihira 3-1-12, Suma-ku, Kobe 654-0037, Japan \\ ${ }^{2}$ School of Humanities for Environmental Policy and Technology, Himeji Institute of Technology, Shinzaike-Honcho, Himeji 670-0092, Japan
}

Received September 24, 2003; Accepted December 13, 2003

\begin{abstract}
Okara was hydrolyzed in subcritical water to increase the inhibitory activity of angiotensin I-converting enzyme (ACE) and soluble dietary fiber (SDF) content. The $\mathrm{IC}_{50}$ of okara and subcritical water-treated okara (SCokara) for $\mathrm{ACE}$ were 11.2 and $4.7 \mathrm{mg} / \mathrm{ml}$, respectively, showing that $\mathrm{SC}$-okara had about 2.4-fold higher inhibitory activity than okara. The SDF content in okara and SC-okara were 3.4 and $17.1 \%$, respectively, showing that SCokara had about 5-fold higher SDF content than okara. Powdered SC-okara or okara was fed to spontaneously hypertensive rats (SHR) at the level of $5 \%$ in a $1 \% \mathrm{NaCl}$ (control) diet for 28 days. On the 14th and 28th days, the SHRs of the SC-okara group showed significantly lower systolic blood pressure compared to the control group. Thus, hydrolysis of okara by subcritical water is an effective technology for increasing ACE inhibitory activity and SDF content, which cause the hypotensive action.
\end{abstract}

Keywords: okara, subcritical water, angiotensin I-converting enzyme, soluble dietary fiber, blood pressure, spontaneously hypertensive rat

Okara is the residue left from ground soybeans after extraction of the water-extractable fraction used to produce soy milk and tofu. Large quantities of okara are burnt in our society. This circumstance makes the development of a system to use this byproduct very important.

Many approaches have been undertaken to use okara, such as fermenting it for human consumption (Matsumoto \& Take, 1980; Matsuo, 1989a, b) or animal food (Sumida et al., 1995). Yamauchi et al. (1994) reported that pepsin digests of okara protein include the inhibitory active peptide against angiotensin I-converting enzyme (ACE), which converts angiotensin I to angiotensin II, which, in turn, constricts arteries and leads to hypertension.

The insoluble dietary fiber (IDF) content of okara is high (about 50\%). On the other hand, the soluble dietary fiber (SDF) content is low (below 5\%). The physiological influence of dietary fiber on human or experimental animals changes with water insolubility or solubility. Generally, SDF is effective in improving hyperlipidemia, diabetes, or hypertension. Yoshii et al. (1996) reported that the solubilization of okara fiber can be performed by acid hydrolysis at $\mathrm{pH} 4.5$ and that hydrolysate can be used as an emulsifier.

More recently, subcritical or supercritical water has began to be used as a reaction medium for the degradation or hydrolysis of higher molecular weight materials such as biomass, because of its low cost and low environmental burden (Harada et al., 1998; Yoshida et al., 1999). We examined the hydrolysis of collagen with subcritical water (Harada et al., 1998) and suspect that, in the subcritical water hydrolysis processing of okara,

*To whom correspondence should be addressed. E-mail: wakita@hyogo-kg.go.jp protein and IDF are hydrolyzed and solubilized, leading to the generation of ACE inhibitory peptides and SDF.

In the present study, the subcritical water was applied to hydrolyze the okara to increase the inhibitory activity of the $\mathrm{ACE}$ and SDF content. In addition, the effect of okara and subcritical water-treated okara (SC-okara) on systolic blood pressure (SBP) in spontaneously hypertensive rats (SHR) was assessed.

\section{Materials and Methods}

Hydrolysis of okara by subcritical water and preparation of SC-okara powder Dried okara was obtained from the Tajimayashokuhin Company (Hyogo, Japan). The experimental apparatus used is shown in Fig. 1. The apparatus is equipped with a slurry pump (Fuji Pump Ltd., Mie, Japan), which can send a viscous solution under high pressure, and a small reaction tube $(3.1 \mathrm{ml})$ that works as a static mixer. Okara slurry sent by the slurry pump is mixed with the preheated water and passes through the static mixer. After hydrolysis, the reactant passes through a control valve (Badger Meter Inc., USA) that can discharge even solution that contains solid particles. This valve can also adjust the inside pressure. The reaction temperature was measured at $10 \mathrm{~cm}$ below the static mixer by using a chromel-alumel thermocouple. The feed rates of the slurry solution and the preheated water were $23 \mathrm{ml} / \mathrm{min}$ and $67 \mathrm{ml} /$ min, respectively. By mixing, the mixture was heated rapidly to the reaction temperature. The hydrolyzation of okara was performed at a temperature of $240^{\circ} \mathrm{C}$ and a pressure of $22 \mathrm{MPa}$, and the residence time was $1.7 \mathrm{~s}$. At the exit of the reactor, the mixture was quickly cooled by a cooling water jacket. The effluent was lyophilized and milled. 


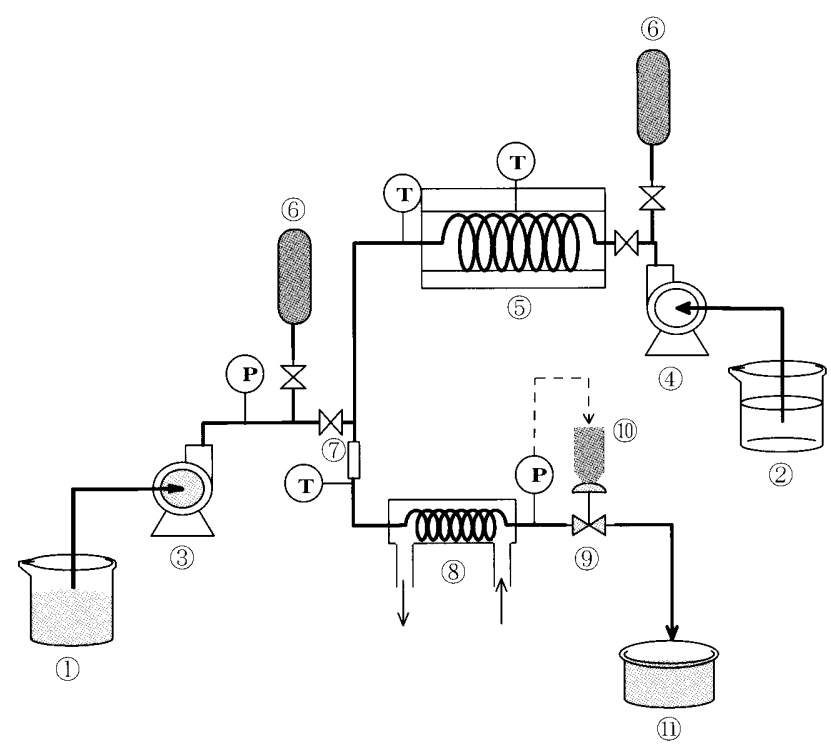

Fig. 1. Schematic diagram of experimental apparatus: 1, okara slurry; 2, water; 3 , pump for slurry; 4 , pump for water; 5 , electric furnace; 6 , damper; 7 , reactor (static mixer); 8 , cooling water; 9 , control valve; 10 , actuator; 11 , effluent.

Measurement of ACE inhibitory activity The ACE inhibitory activity was assayed by a method of Cushman \& Cheung (1971) with some modification. Hippuryl-His-Leu-OH (HHL) (Bachem Feinchemikalien AG, Bubendort, Switzerland) was dissolved in $125 \mathrm{mM}$ sodium borate buffer, $\mathrm{pH} 8.3$, containing $500 \mathrm{~mm} \mathrm{NaCl}$. Twenty-five $\mu \mathrm{l}$ of a $6.5 \mathrm{mM}$ HHL solution was mixed with $10-\mu$ l of a sample solution $(0.8 \mu \mathrm{m}$-millipored), and then pre-incubated for $3 \mathrm{~min}$ at $37^{\circ} \mathrm{C}$. The reaction was initiated by the addition of $10 \mu \mathrm{l}$ of an ACE solution in $125 \mathrm{~mm}$ sodium borate buffer $(100 \mathrm{mU} / \mathrm{ml})$, and the mixture was incubated for $60 \mathrm{~min}$ at $37^{\circ} \mathrm{C}$. The reaction was stopped by the addition of $10 \mu \mathrm{l}$ of $1 \mathrm{~N} \mathrm{HCl}$. The hippuric acid liberated by the ACE reaction was extracted with $200 \mu$ l ethyl acetate, and the solvent was removed by vacuum evaporation. The content was dissolved by the addition of $300 \mu \mathrm{l}$ of distilled water, and its UV spectra density at $228 \mathrm{~nm}$ was measured. The extent of inhibition was calculated as follows: $(B-A) /(B-C) \times 100$ where $A$ is the UV spectra density in the presence of ACE and a test sample, $B$ is the UV spectra density without a test sample, and $C$ is the UV spectra density without ACE. Inhibition was expressed as the concentration of the sample that inhibited $50 \%$ of the ACE activity $\left(\mathrm{IC}_{50}\right) ; 1$ unit of ACE inhibitory activity was expressed as the potency showing $50 \%$ of ACE inhibition under these conditions.

Measurement of SDF and IDF contents Zero point five to $2.5 \mathrm{~g}$ of the samples was subjected to measurement of the SDF and IDF content by the modified Prosky method (1988). Both SDF and IDF were filtered by suction with a GA100 glass filter (ADVANTEC, Tokyo, Japan).

GPC analysis of SDF A Waters Co. system (multisolvent delivery system 600 and refractive index detector 2414) with Superdex 200HR 10/30 column (Pharmacia) was used. Thirty milligrams of each SDF fraction was dissolved in $1.2 \mathrm{ml}$ of $0.2 \mathrm{M}$ sodium phosphate buffer at $\mathrm{pH} 6.8$, and $60 \mu \mathrm{l}$ of this solution was injected. The eluent was a buffer with $0.2 \mathrm{M}$
Table 1. Composition of tested diets.

\begin{tabular}{lccc}
\hline Constituents $(\%)$ & Control & Okara & SC-okara \\
\hline Casein & 22 & 20.775 & 20.775 \\
Lard & 10 & 9.325 & 9.325 \\
Mineral mixture* & 3.5 & 3.5 & 3.5 \\
Vitamin mixture* & 1.0 & 1.0 & 1.0 \\
Choline bitartrate & 0.2 & 0.2 & 0.2 \\
Sodium chloride & 1.0 & 1.0 & 1.0 \\
Cellulose & 3.0 & 0.47 & 0.47 \\
Saccharose & 59.3 & 58.73 & 58.73 \\
Okara & & 5.0 & 5.0 \\
SC-okara & & & \\
\hline
\end{tabular}

* The vitamin and mineral mixture were those of AIN-96 (American Institute of Nutrition, 1996)

Table 2. Component concentrations in okara and SC-okara.

\begin{tabular}{lcc}
\hline \multicolumn{1}{c}{ Contents $(\%)$} & Okara & SC-okara \\
\hline Protein & 24.5 & 23.7 \\
Fat & 13.5 & 12.8 \\
Carbohydrate & 4.4 & 6.2 \\
Soluble dietary fiber & 3.5 & 17.1 \\
Insoluble dietary fiber & 47.1 & 31.0 \\
Ash & 4.0 & 3.9 \\
Moisture & 3.0 & 5.3 \\
Water soluble fraction & 20.3 & 39.7 \\
\hline
\end{tabular}

sodium phosphate at $\mathrm{pH} 6.8$ and its flow rate was $0.75 \mathrm{ml} / \mathrm{min}$.

Animals and diets Eighteen 9-week-old male spontaneously hypertensive rats (SHR) were obtained from Hoshino Animals (Tokyo). The animals were maintained according to Notification No. 6, March 27, 1980 of the Prime Minister's Office in a temperature-controlled room $\left(23 \pm 1^{\circ} \mathrm{C}\right)$ with a $12 \mathrm{~h}$ light cycle. After an acclimation period of 1 week, during which the rats were fed a commercial diet (CE-2, CLEA, Tokyo), they were divided into three groups based on their systolic blood pressure (SBP), then fed one of the test diets (Table 1). Five percent of okara and SC-okara were respectively added to the $1 \% \mathrm{NaCl}$ diet. Between the okara and control groups, the components of the protein, lipid, and dietary fiber content were adjusted using casein, lard, and cellulose, respectively. The rats were given free access to food and water. Every 7 days after feeding the test diets, SBP was measured by a tail cuff using a commercially available system (Model MK-2000, Muromachi Machine, Tokyo).

Statistical analysis SBP was expressed as means \pm SD. The data were subjected to a one-way ANOVA. When significant $\mathrm{F}$ ratios were found, the okara and SC-okara means were compared with those of the control group by Dunnett's test (SPSS ver.8, SPSS Japan Inc., Tokyo). Statistical significance was accepted at $p<0.05$.

\section{Results and Discussion}

We performed hydrolysis of okara using subcritical water with a custom-made apparatus designed such that continuous reaction could be carried out. The hydrolyzation of okara was studied at a temperature of $240^{\circ} \mathrm{C}$ and a pressure of $22 \mathrm{MPa}$, and the residence time was $1.7 \mathrm{~s}$. The solubilization rate of okara and SC-okara were 20.2 and $39.7 \%$, respectively (Table 2). Thus, it was possible to hydrolyze okara with our equipment in a short reaction time without adding a catalyst. 
Table 3. ACE-inhibitory activity of okara and SC-okara.

\begin{tabular}{ccc}
\hline & Okara & SC-okara \\
\hline $\mathrm{IC}_{50}(\mathrm{mg} / \mathrm{ml})$ & 11.2 & 4.7 \\
\hline
\end{tabular}

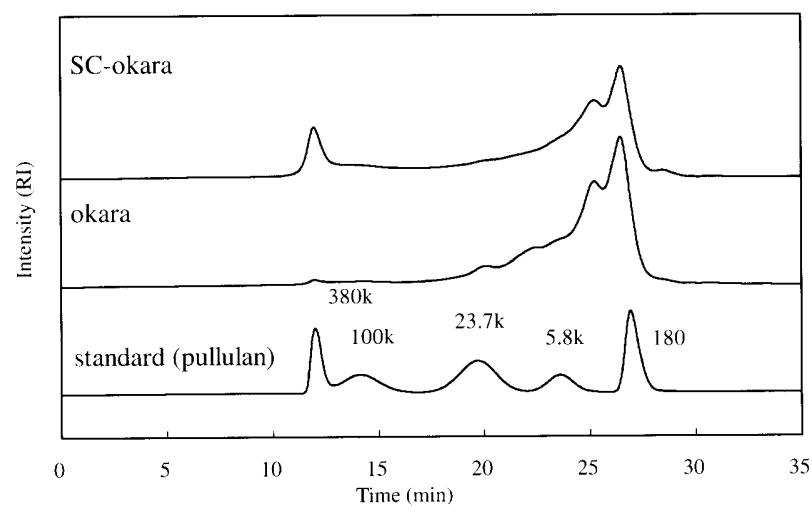

Fig. 2. GPC curves of water soluble dietary fiber. Conditions: Column, Pharmacia Superdex 200HR 10/30; eluent, $200 \mathrm{~mm}$ sodium phosphate $\mathrm{pH}$ 6.8; flow rate, $0.75 \mathrm{ml} / \mathrm{min}$

As shown in Table 3, $\mathrm{IC}_{50}$ of okara and SC-okara were 11.2 and $4.7 \mathrm{mg} / \mathrm{ml}$, respectively. SC-okara showed about 2.4-fold higher inhibitory activity than okara against ACE. Yamauchi et al. (1994) reported that pepsin digests of okara protein include the active peptides with ACE inhibitory activity. Maruyama et al. (1997) studied the hydrolysis of the protein of the corn in sub- and supercritical water to prepare the peptide making its utilization possible as a food and medical substace. We suspect that a portion of the protein of okara is hydrolyzed by the subcritical water, leading to the generation of ACE inhibitory activity peptides.

The SDF content in okara and SC-okara were 3.4 and $17.1 \%$, respectively, showing that SC-okara had about a 5-fold higher content than okara (Table 2). In general, heat processing causes the solubilization of insoluble hemicellulose and pectic substances, leading to a transfer to the soluble fraction and an increase in SDF content (Schrumpf \& Charley, 1975; Lintas \& Cappelloni, 1988; Takase \& Teramoto, 1989; Takeyama et al., 2002). In this context, insoluble hemicellulose and pectic substances of okara could be detached from cellulose and hydrolyzed to cause a shift to the water soluble fraction by subcritical water processing.

The molecular weight distribution of the SDF fraction was measured (Fig. 2). Each GPC curve shows an equal amount of the soluble component. A small peak was observed near the exclusion limit $(853 \mathrm{kDa})$ in okara, while in SC-okara, a peak larger than that in okara at the exclusion limit was observed. Moreover, the base line of SC-okara shifted upwards compared with that of okara, suggesting that subcritical water causes the increase of broad molecular-weight range hemicellulose and pectic substances.

It has been reported that dietary soy protein exerts antihypertensive activity when compared to a casein-based diet in SHR (Nevala et al., 2000; Martin et al., 2001). Wu \& Ding (2001) have demonstrated that $\mathrm{ACE}$ inhibitory peptides prepared from

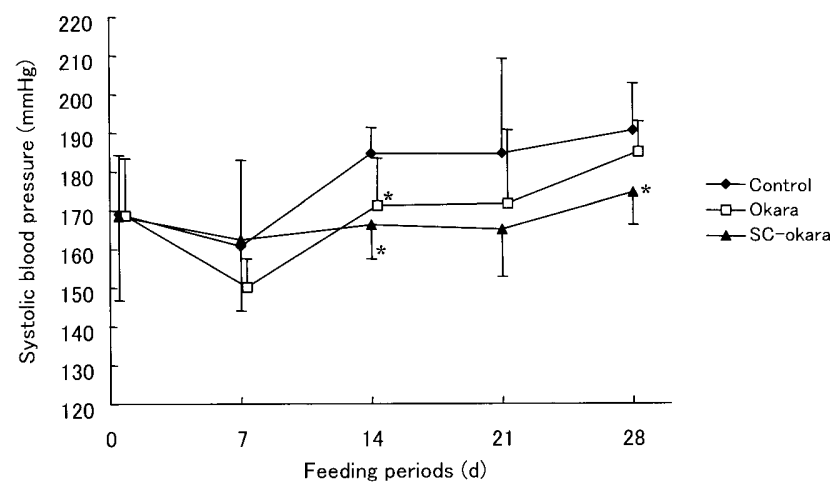

Fig. 3. Changes in systolic blood pressure in SHR during the feeding period. Data are means \pm SD for 6 male rats. Values with * are significantly different in comparison with the control group $(p<0.05)$.

soy protein by the action of alcalase enzyme decreased SBP when peptides were orally administered to SHR. Although okara contains about $25 \%$ protein, and the ACE inhibitory peptides could be recovered from okara (Yamauchi et al., 1994), there is little information on the effect of okara on SHR. In the present study, we examined the effects of SC-okara and okara on $1 \% \mathrm{NaCl}-$ loaded SHR.

At the start of the animal study, the mean initial body weights (control: $235 \pm 15$ g, okara: $238 \pm 15 \mathrm{~g}$, SC-okara: $244 \pm$ $6 \mathrm{~g}$ ) of each group were not statistically different. Body weights and food intake were recorded almost everyday throughout the study. The body weight of rats in the control, okara and SC-okara groups at the end of the experiment were $307 \pm 22,305 \pm 16$ and $313 \pm 8 \mathrm{~g}$, respectively. No effect of diet on food intake or body weight was seen.

Figure 3 shows the changes of SBP in SHR. On day 14, the SBP rates of rats in the control, okara and SC-okara groups were $185 \pm 7,171 \pm 12$ and $166 \pm 9 \mathrm{mmHg}$, respectively, showing that the values in both the SC-okara and okara groups were significantly lower than in the control group. On day 28 , the SBP rates in those groups were $191 \pm 12,185 \pm 8,175 \pm$ $8 \mathrm{mmHg}$, respectively, indicating that the value of only the SCokara group was significantly lower than that of the control group. The changes in SBP show a tendency to suppress the rise of blood pressure in the okara group in comparison with the control group, and that SC-okara suppressed the rise of blood pressure further. However, whether SC-okara and okara diets could decrease SBP when hypertension has already developed is still unclear. Dietary $\mathrm{Na}$ is one of the major risk factors for hypertension. Kodama et al. (1996) reported that soluble hemicellulose recovered from wheat bran has a suppressive effect on blood pressure in SHR, and that SHR fed soluble hemicellulose showed increased excretion of $\mathrm{Na}$ in their feces compared with the control ( $1 \% \mathrm{NaCl}$ loaded) SHR that were fed no hemicellulose. We suspect that the attenuation of the rise of SBP that is caused by SC-okara is due to concomitant increased ACE inhibitory activities and SDF, which suppress the conversion of angiotensin I to angiotensin II and facilitate the excretion of $\mathrm{Na}$ in the feces.

In conclusion, the present study demonstrated that hydrolysis by subcritical water is an effective technology for increasing 
the ACE inhibitory activity and SDF content of okara, and that SC-okara reduced the development of hypertension in SHR. Further work is in progress to identify the ACE inhibitory materials.

Acknowledgment We are grateful to Dr. Watanabe Toshiro (Yaegaki Technology Development Laboratories, Yaegaki Bio-industry, Inc., Himeji, Japan) for providing valuable information.

\section{References}

Cushman, D.W. and Cheung, H.S. (1971). Spectrophotometric assay and properties of the angiotensin-converting enzyme of rabbit lung. Biochem. Pharmacol., 20, 1637-1648.

Harada, O., Sumita, S., Arima, S. and Sugita, M. (1998). Hydrothermal treatment of calf collagen and property of the decomposition products (in Japanese). Hikakukagaku, 44, 194-199.

Kodama, T., Shiiba, K. and Tsuji, K. (1996). Suppressive effect of wheatbran hemicellulose on blood pressure in spontaneously hypertensive rats (in Japanese). Nihon Eiyo Shokuryo Gakkaishi (J. Jpn. Soc. Nutr: Food Sci.), 49, 101-105.

Lintas, C. and Cappelloni, M. (1988). Content and composition of dietary fiber in raw and cooked vegetables. Food Sci. Nutr., 42F, 117-124.

Martin, D.S., Breitkope, N.P., Eyster, K.M. and Williams, J.L. (2001). Dietary soy exerts an antihypertensive effect in spontaneously hypertensive female rats. Am. J. Physiol. Regul. Integr: Comp. Physiol., 281, R553-R560.

Maruyama, S., Hatada, K., Ikushima, Y., Saito, I. and Mitsuyoshi, S. (1997). Production of amino acid or peptide from protein by using super critical water and food, feed, medium for culturing microorganism and medicine. Japan Kokai Tokkyo Koho, 09-268166. Oct. 14.

Matsumoto, H. and Take, T. (1980). Studies on the utilization of tofukasu (okara). II. Selection of Bacillus natto strain (in Japanese). Niigata Daigaku Kyoikugakubu Kiyo, Shizen Hen (Mem. Fac. Educ., Niigata Univ., Nat. Sci.), 22, 53-63.

Matsuo, M. (1989a). Morphological and physicochemical properties and composition of "okara" fermented with Rhizopus oligosporus (in Japanese). Nihon Eiyo Shokuryo Gakkaishi (J. Jpn. Soc. Nutr: Food Sci.),
42, 173-178.

Matsuo, M. (1989b). Morphological, compositional and physicochemical properties of "okara" fermented by Aspergillus oryzae (in Japanese) Nippon Nogeikagaku Kaishi (J. Agric. Chem. Soc. Jpn.), 63, 17651770.

Nevala, B., Vaskonen, T., Vehniainen, J., Korpela, R. and Vapaatalo, H. (2000). Soy based diet attenuates the development of hypertension when compared to casein based diet in spontaneously hypertensive rat. Life Sci., 66, 115-124.

Prosky, L., Asp, N.G., Schweizer, T.F., Devries, J.W. and Furda, I. (1988). Determination of insoluble, soluble, and total dietary fiber in foods and food products: interlaboratory study. J. Assoc. Off. Anal. Chem., 71, 1017-1023.

Schrumpf, E. and Charley, H. (1975). Texture of broccoli and carrots cooked by microwave energy. J. Food Sci., 40, 1025-1029.

Sumida, M., Yuhki, T., Chen, R., Mori, H., Imamura, and Matsubara, F. (1995). Aspectic rearing of original silkworm strains on an artificial diet throughout the entire larval instars (in Japanese). J. Sericult. Sci. Jpn., 64, 35-38.

Takase, M. and Teramoto, Y. (1989). Heat changes in the properties of carrot pectin (in Japanese). Chorikagaku, 22, 283-289.

Takeyama, E., Fukushima, M. and Tanimura, A. (2002). Effect of heattreatment on the content and polysaccharide composition of dietary fiber. Food Sci. Technol. Res., 8, 125-130.

Wu, J. and Ding, X. (2001). Hypotensive and physiological effect of angiotensin converting enzyme inhibitory peptides derived from soy protein on spontaneously hypertensive rats. J. Agric. Food Chem., 49, 501-506.

Yamauchi, F., Jiun, R.C., Muramoto, K., Iwabuchi, S., Asano, M. and Suetsuna, K. (1994). Isolation and utilization of the protein from "okara" (in Japanese). Rep. Soy Protein Res. Commun., 15, $22-27$.

Yoshida, H., Terashima, M. and Takahashi, Y. (1999). Production of organic acids and amino acids from fish meat by sub-critical water hydrolysis. Biotechnol. Prog., 15, 1090-1094.

Yoshii, H., Takeshi, F., Maeda, H. and Mori, H. (1996). Hydrolysis kinetics of okara and characterization of its water-soluble polysaccharides. Biosci. Biotechnol. Biochem., 60, 1406-1409. 